\title{
Approaching Hysteria and Abjection through Freudian Reading of Toni Morrison's Paradise
}

\author{
Maha Yasir Abed*, Lajiman Bin Janoory \\ Faculty of Languages and Communication, Universiti Pendidikan Sultan Idris, Malaysia \\ Corresponding Author: Maha Yasir Abed, E-mail: Maha_Yassir@Yahoo.Com
}

\section{ARTICLE INFO}

Article history

Received: May 04, 2018

Accepted: August 11, 2018

Published: November 01, 2018

Volume: 7 Issue: 6

Advance access: September 2018

Conflicts of interest: None

Funding: None

\begin{abstract}
This paper examines the representation of hysteria in Toni Morrison's Paradise. The study will mainly focus on the psychological traits of the female protagonists. Such traits provide amble instance of the influence of hysteria on the protagonists' conscious behavior. For this reason, the primary conceptual formwork will be psychoanalysis. Accordingly, Sigmund Freud's concept of hysteria will be applied to interpret the hysteric symptoms which result from harmful sexual experiences like rape, molestation and violation in a male dominated society. In this regard, the protagonist's suffering from hysteric symptoms, like fear, silence, nightmare, and many other symptoms are going to be scrutinized in order to identify the influence of hysteria on the protagonist's reaction. Freud asserts that sexual experience or molestation that occur within childhood is the main source of hysteria which appear later. Thus, this paper will illustrate the causes that lead the protagonist to be hysteric from Freudian perspective and emergence of self- actualization to gain subjectivity and independence.
\end{abstract}

Key words: Freud, Hysteria, Psychoanalysis, Self- actualization, Morrison, Paradise

\section{INTRODUCTION}

In Freud $A-Z$, Heller (2005) traces the evolution of the concept of hysteria in the science of psychoanalysis. Heller maintains that the concept of hysteria refers to psychical phenomenon connected with women's productive body parts. More specifically, the concept of hysteria began as a reaction to understand some deformation in women's wombs. Women suffered from some problems in their wombs which make them suffer from psychic disorder. Heller finds that the Greek word "hystera" precisely means "uterus" which is used interchangeably with womb. The primal motive of women's sufferings was thought to be an unstable position of the womb in women' bodies. The arbitrary movement of the womb in the females' body resulted in psychically disordered behaviors, such as uncontrolled provisional spasm (paralysis) that continues for short time.

Hysteria, as a term can be used to refer to a person who has any psychoneurotic symptoms (Mijolla, 2005). Hysteria has been studied as a phenomenon in literary dialogue, (Wald,2007) to explores the connection among hysteria, trauma and melancholia with relation to the interpretations of Freud and Lacan. Hysteria is shown by some scholars as Helene Cixous, Catherine Clement, Luce Irigaray, Elaine Showalter and others, as a powerful kind in discussing "the relegation of feminine subjectivity that is fundamental in patriarchal. western cultures" (p.2). Those critics exposed the role of the hysteric as a character who fluctuates between victimhood and rebellion in a male- inscribed discourse.
The American theorist, Showalter (1985), follows a careful research tracing the elements found in the society which might help in developing hysteria and madness simultaneously. Showalter's virtue lies in her shifting hysteria from the clinic to the library and from medical circles studies to literature. Thus, "hysteria has developed its own prototypes, archetypes and plots" (p.6). Showalter has made a significant change in the field of hysteria by adding new terms. She states "what used to be called hysteria is now diagnosed as conversion disorder, somatization disorder or dissociative personality disorder" (p.17)

Generally, all of the interpretations of hysteria are Freudian as his researches on hysteria began in the nineteenth century fin de siècle when he proved his success and talent in his theories. His ideas on hysteria were developed primarily due to his treatment of the case histories and the most famously written of which were about Anna O. and Dora. His ideas on hysteria developed since his first well-known work Studies on Hysteria in 1895 which was the starting line of psychotherapy in general and of psychoanalysis especially (Verhaegen, 1999).

In his influential study, Studies on Hysteria, he claimed that hysteria appears as a result of certain traumatic incidents, which are excluded from consciousness. The repressed memories of unresolved traumas, which lie in the unconscious, are consciously converted into bodily symptoms such as; cough, limps, convulsions or linguistic distortions, and many other symptoms. In Breuer and Freud 
(1957), Freud says that hysterical symptoms are only "psychical traumas and consequently, any practice which calls up distressing affects such as those of anxiety, shame, fright, or any physical pain may function as a trauma of this kind" (p.6). Thus, the psychical trauma operates as the motivator for the presence of hysterical symptoms. And that does not cause the symptom, as Freud mentioned, but instead, it acts as an irritation, a foreign body, an invading intruder applying the invaded body 's own defensive responses. Freud, states that fright is also a breeder of hysterical symptoms within a child or an adult. Also, he attributed most causes of hysteria to a sexual abuse forced on a child, a teen or a woman. "Thus, I put forward the hypothesis that at the bottom of all cases of hysteria there are one or more incidences of sexual experience”. (p.103)

In short, Freud was eager to show that sexuality supplied the stimulating power for each symptom and the appearance of symptoms is to intervene in the working of the process which characterizes hysteria manifestation of symptom. Freud stresses many times that sexuality is central to the problem of psychoneurosis and of the neuroses in general, and this is exactly like the case of Seneca, the heroine of Paradise, her hysteria is awakened by two major events that has already traumatized her: the memory of her sister's abandonment and its influences on her which will be discussed in detail later, and the acts of molestation she was exposed throughout her childhood and adulthood. Hysteria can be represented through disturbing behaviors acted out by Seneca, like disturbed sleep, nightmares, loss of speech(silence), hurting the self and other such behaviors. Thus, this paper aim to display the reasons which lead to the appearance of hysterical symptoms on female characters and how it influences their behavior and finally the strategies through which female get rid of these hysterical behaviors and regain their identity to construct their subjectivity.

\section{HYSTERIA: THE DUALITY OF FRIGHT OF ABANDONMENT AND SEXUAL ENCOUNTERS}

Hysteria is one of the most obvious aspects of psychic disorder. Hysteric persons suffer from abnormal behaviors that make other people notice their whimsical reactions towards situations and events. In Breuer and Freud (1957), Freud contends that hysteria relates to family affairs. He says that trauma is the main source of hysteria and the repressed memories lead to trauma as psychic abnormality. Toni Morrison deals with women's suffering in general and black females in particular. Since her first novel The Bluest eyes and a long four decades till now, Morrison gives us a real depiction of black females' dilemma and what does it mean to be a black and a female. Her novels are the mirror which reflects the dangerous influences of these sufferings on females' psyches. In her novel Paradise, the protagonist Seneca repressed her memory about her sister Jean, (actually her mother) and how she left her a lone during these five nights and four days before she realizes that she will never see her again. She tries to do everything that pleased her sister instead of bothering her: "the third day, she began to understand why Jean was gone and how long to get her back. She cleaned her teeth and washed her ears carefully. She also flushed the toilet right away, as soon as she used it, and folded her socks inside her shoes" (p.127). In this quote, Seneca is only five years old and she is abandoned by her sister Jean whom she loves. She always sees her sister's apparition. This means that she suffers from loneliness. She needs her sister to be with her side. For this reason, the abandonment of her sister leaves deep negative void in her psyche. According to Freud (1975), the fright of abandonment is one representative sign of hysteria.

In other scenes, it is only on the sixth day, when Seneca "after her unanswered prayers, bleeding gums and hunger, she climbed on a chair to have a piece of bread she found a letter and though she is only five years and didn't know reading, yet she recognizes her name and Jean's name". At that point, Seneca tried to keep the letter in her shoes; and she does everything to please the others, to satisfy others become the most important thing in her life as she didn't want the others to abandon her like her sister Jean; who is actually her mother. She goes astray looking for her sister. Morrison depicts her wandering state through six days:

fifteen years ago, when the brokenhearted hitcher was five years old, she had spent four nights and five days knocking on every door in her building. "is my sister here?" That was 1958, when a child could play all over brand-new government housing in safety. The first two days, she waited Jean, her sister, would be coming back anytime now, because dinner food was on the table. The third day she began to understand why jean was gone and how to get her back. She cleaned her teeth and washed her ears carefully. She also flushed the toilet right away, and folded her socks inside her shoes. Meantime the nights were terrible. On the fourth day, having brushed her teeth until the toothbrush was pink with blood. The sixth day, demoralized by unanswered prayers, bleeding gums and hunger she gave up goodness, climbed up on a chair and opened the bread box, and pulled out a single sheet of paper with more lipstick words. She could not understand any except her own name again at the top, "Jean" at the bottom, loud red marks in between. (pp. 126-127)

Seneca is profoundly influenced by the loss of her sister. It is obvious form the above quotation that she needs her sister. Her attempts to please other exemplify her psychic need not to be abandoned and that make her submissive and obedient. She tries to attract the attention of other people to be with her side and not to abandon her. She becomes close to the other people to make them sympathize with her state. In fact, she looks for the sense of belonging to others to compensate the absence of her sister. This strenuous search for belonging to people is an indication of her fright of abandonment. Freud (1962) describes this experience as a sign of hysteria in its early phases. The fright of abandonment begins with hysteric people find themselves thrown in an abnormal family atmosphere. They feel that they are left by their most loved persons. In Paradise, Seneca, similarly suffers from this experience as she loses her sister who represents her family background. "Fright of abandonment, similarly, might be a result of losing one's family members" (Freud, 1962). 
In Paradise, Fright of abandonment repressed in Seneca's memory and perplexes her too much till the end of the novel, Seneca was eager to know why her mother Jean abandoned her. The trauma of abandonment repressed in her memory and appear from time to time as a nightmare of a crying woman, it is the same "tall woman who walked past the window that night when she was alone at home, no coat and nothing on hear head, she touched her eyes with the back of her arm, the inside of her wrist. She was crying" (p.127). This trauma is motivated by triggering rape at the foster care where Seneca sees the same dream again: "she thought of the crying woman briefly then, more later, until the sight of her became an occasional heart-breaking dream" (p.128). The triggering of repeated rape makes Seneca lives in a continuous panic which she cannot distinguish from her everyday life: "finally her panic subsided and the screams of a hurt woman were indistinguishable from every day traffic" (p.135). for this reason, she strongly keeps the letter because it is a reminder of Jean who incarnate the notion of belonging to family: "but it was the letter, safe in her shoe, that made leaving with the caseworker for the first of two foster homes possible. She thought about the crying woman briefly then, more later, until the sight of her became an occasional heartbreaking dream" (p.128). Jean, here, plays a groundbreaking role. She embodies the sense of belonging to family and home. However, her absence makes Seneca disturbed. Freud (1900) argues that family represents a substantial part of person's psychic stability; and the loss of one of the family members would leads to a sense of fright and unjustified fear.

Nevertheless, Seneca never cries along her life, even when she was only five years old and found herself alone at the house; she spent five nights and four days alone waiting her sister to return to have the dinner as it is on the table. Being so, she shows great fortitude. So, Seneca in spite of all the plights that she faces but she never shed any tears. She used to do whatever the other want, satisfied with everything, hide her pain but never cry: "she had not shed one even when she found Jean's letter next to the Lorna Doone. Well cared for, loved, perhaps, by the mother in both of the foster homes, she knew it was not herself that the mothers had approved of but the fact that she took reprimand quietly, ate what given, shared what she had and never ever cried" (p.135). Consequently, Seneca used to be a peacemaker, the one who never object or refuse: "Always the peacemaker. The one who said yes or I don't mind or I'll go. Otherwise- what? They might not like her. Might cry. Might leave. So, she had done her best to please, even if the Bible turned out to be heavier than the shoes" (p.131). This peaceful state embodies her psychic demands. She needs other people to make up for the loss of Jean. Freud (1895) claims that the need of other people comes out of the loss relatives in the same family.

This abandonment influences on Seneca's personality, to use Freud's (1895) words, that her hysteric character become obedient, simple, and hesitant. Seneca carries the letter that she found from her sister in her shoes for the long of her life and till the end of the novel she wonders why Jean left her; and the nightmare of the crying woman never leaves her till the rest of her life.
Freud, in all his researches asserts that sexuality is the basis of all psychic diseases which hysteria is one of them, regardless whether these acts are real or only fantasies. According to Freud, only "physical traumas" and accordingly "any experience which calls up distressing effects such as those of fright, anxiety, shame or physical pain" can lead to hysterical symptoms (Breuer \& Freud 1957, p. 26). In this novel, when Seneca's mother didn't come back, one of the neighbors took her to the foster care. At the foster care, Seneca encounters the first molestation which affects her psyche and leads her to display hysterical symptoms. When Harry, her foster brother, got her under wear off and got to her panties and her stomach was scratched with the pin of her jeans and the line of blood excited him more and she didn't know whether the blood is because of the pin or because of Harry, it didn't hurt and she doesn't cry also, and it is from that incident Seneca express the hysterical behavior of cutting her body and let the line of blood run on it. When Mama Greer sees the scars' scratch on her stomach, she sympathizes with her but when Seneca tells her about Harry, she blames her and moves her to another foster house. There, Seneca also is sexually abused by a junior boy but this time she does not speak as she knows that they will blame her. Another time, when Seneca passed the street, a man was sitting with his baby daughter. The man was in position of sexual eroticism. This attracts her attention because it reminds her of the sexual encounter with the boy at the foster house: "it was then he lifted his penis out and made kissing noises" (p.261). She becomes extremely surprised by this abrupt incident.

Even her boyfriends, abused her thus she felt that there is something wrong within her as she is molested by all men she faces in her life: "Refuge with boyfriends was no better. They took her devotion for granted, but if she complained to them about being fondled by friends or strangers their fury was directed at her, so she knew it was something inside, that was the matter. She entered the vice like a censored poet whose suspect lexicon was too supple, too shocking to publish" (p.261). According to Freud (1895), such sexual experience is considered as the main cause of hysteria. This is due to the fact that hysteria has a close affinity with sex and its relative experiences. Seneca, again, suffers from these experiences in her life. Yet, she endures all these sexual encounters and never speak because she loses Jean. Consequently, she becomes a victim of sexual molestation. In this respect, both family and society are two inextricable factors of causing her hysteria.

By time, Seneca distorts her body. She uses a razor to deform her body by cutting some wounds on her skin. This reaction is an indication of her hysteric psyche as she begins to make her body bad. She wants to thwart men's desire to have her body for sexual desires. Seneca, thus, scratches her hand and thigh with razor or everything in front her eyes, she made a tree of scratching her thigh after each time, she was raped in and "yelps with pain from stranger's penis" (p.264). Thus, Seneca's hysterical behavior of hurting herself is an embodiment of the destruction of Seneca's psyche which results of her sexual molestation. The frequent sexual encounters make her hysteric. She distorts her body for the sake 
of psychic relief. Yet, she fails. In Freud's (1895) words, she tries to avoid men's moderation acts. These men are the "subjects" that make her suffer from sexual encounters. This hysterical hurt of her body accompanied with her inability to speak or express herself, which is another symptom of hysteria called aphasia. Freud had termed aphasia as a hysterical figuring symptom. Seneca's aphasia is the cumulative effect of continuous sexual molestation since her childhood.

\section{ABJECTION: CONSOLATION AND PSYCHIC RELIEF}

The concept of abjection denotes the consolation situations. Freud and Bruere ((1957) had provided a successful remedy of talking cure, which they follow in treating their patients Anna $\mathrm{O}$ and Dora, talking cure or what is known today as psychotherapy is a device which is used by Freud in which he encourages his patients to retell the incidents that make them hysteric, by this he helps them to articulate their fears and traumas which are hidden in their unconscious and only come to surface in a hysteric symptom. Through the talking cure, the patient finds catharsis. Freud later used this technique successfully to treat all his patients and since that the technique of talking cure is used successfully by psychiatrics.

In Morrison's Paradise, the deprivation of women rights and voice and reduce their role to housekeeping, production and pleased male, women are placed as an object in their society. But women revolt against their dilemma and begin to gradually obtain their identity, they flee from Ruby and its male domination and find shelter in Convent which is inhabited only by women who depend on each other in everything. Seneca arrives at Convent after she failed to convince Eddie's mother to get Eddie out of jail. Seneca finds herself aimless and purposeless, all she has is $500 \$$ which she kept in her shoes, she doesn't know what to do or where to go.

when she is left alone. She could not decide where to go. Only her boyfriend Eddie used to make decision for her before he is taken into prison. She is now completely lost: "At a loss, as to where to go or what to do. Get a job near the prison and stand by him? Meaning follow his instructions, apologize for not getting his mother's savings. Go back to Chicago? pick up her life-before-Eddie? Instant friends. catch- quick jobs. Temporary housing. Stolen food. Eddie Turtle had been settled life to her for six months and now he was gone" (p.138). She does not find meaning in her life. She decides to get into a car and go to whatever place: "so she accepted the risk of stowing away in trucks. She preferred traveling resolutely nowhere, closed off from society, hidden among quiet cargo- no one knowing she was there. When she found herself among crates in a brand- new'37 pick up, jumping out of it to follow a coatless woman was the first pointedly uninstructed thing she had ever done" (p.138).

The Covent was her true "habitat." When she arrives at the Convent, she met Mavis, Gigi and Consolata. Consolata is the first one who comes to the Convent with Mary Morgan thirty years ago, she is now fifty years and she plays an important role in guiding all the women who came to the Convent to forget their grief and suffering, to depend on themselves and to be strong and have their voice. She taught them how to control themselves, how to control their pain and memories:

over the past eight years they had come. The first one, Mavis, during Mother's long illness, the second right after she died. Then two more. Each one asking permission to linger a few days but never actually leaving. Now and then one or another packed a scruffy little bag, said goodbye and seemed to disappear for a while- but only a while. They always came to stay on, living like mice in a house no one, not even the tax collector, wanted, with a woman in love with the cemetery. Consolata looked at them through the bronze or grey sunglasses and saw broken girls, frightened girls, week and lying. (p.222)

Consolata, as her name denotes, encouraged them to dream loudly, how to retell their experiences, retell all the bad memories and difficulties loudly and in front of the other women, they discuss each one's experience, remember it and face it: "in loud dreaming, monologue is no different from a shriek; accusations directed to the dead and long gone are undone by murmurs of love. So, exhausted and enraged, they rise and go to their beds vowing never to submit to that again but knowing full well they will. And they do" (p.264). According to Freud, (1975) sharing tragic experiences is a manifestation of abjection. People with hysteric symptoms could be relived through sharing other people's experiences. Thus, in Convent, Seneca learn how to face her fear and past. She used to cut herself with a knife or a razor to see her blood running out of her body: "she was secretly slicing her thighs, her arms. Wishing to be the queen of scars, she made thin red slits in her skin with whatever came to hand: razor, safety pin, paring knife" (p.222). This action is an indication of her hysteric behavior. She is still influenced by her hysteric sexual experiences. She feels happy and relieved when she sees her blood. She is happy with the arboreal scars on her body. She also used to wash her body to hide the blood with some handkerchiefs.

Consolata told women about her story to encourage them. She told them that body is nothing, but the soul is the most important thing. Then, women began to tell their stories. They loudly told each other of their dreams and what happened to them when they came to the Convent. These stories are the remedial strategies to get rid of their tragic experiences because abjection, according to Freud, comes from sharing others' experiences. They easily told their stories as they were really motivated by Consolata:

That is how the loud dreaming began. How the stories rose in that place. Half-tales and the never-dreamed escaped from their lips to soar high above guttering candles, shifting dust from crates and bottles. And it was never important to know who said the dream or weather it had meaning. in spite of or because their bodies ache, they step easily into the dreamer's tale. They enter the heat in the Cadillac, feel the smack of cold air in the Higgledy Piggledy. They spoke to each other about what had been dreamed and what had been drawn. Are you sure she was your sister? Maybe she was your mother. 
Why? Because a mother might, but no sister would do such a thing. (p.264)

Women, in the Convent, told their stories in both cases; in loud voices and their recalled the events of their stories in their monologues: "in a loud dreaming, monologue is no different from a shriek; accusation directed to the dead and long gone are undone by murmurs of love. So, exhausted and enrages, they rise and go to their beds vowing never to submit to that again but knowing full well they will. And they do" (p.264). They swore not to repeat these tragic experiences again.

Seneca narrates her story to the other women, they even discuss about her mother's abandonment and at the end of the novel, she is no longer a hysterical woman, when she feels that she wants to cut her thigh, she instead scratched the body lying on the cellar floor and no longer hurt herself: "Seneca duplicated in Robin's egg blue one of her more elegant scars, one drop of red at its tip. Later on, when she had the hunger to slice her inner thigh, she chose instead to mark the open body lying on the cellar floor" (p.265). Seneca does not cut her thigh and let blood run because she is no longer that weak, submissive, silenced, and aimless woman. She is no longer doing everything to satisfy the others, especially men. In the Convent, Seneca lives peacefully with other women; and they support one another, they don't hide anything and they are not afraid of anything. Thus, Seneca shares these women's experiences and she becomes relieved of her hysteric behaviors, like cutting herself.

\section{CONCLUSION}

This paper indicates one of the problems facing the female characters of Toni Morrison's novels. These characters represent hysteric symptoms which result from sexual molestations, rape and violation in a male dominated society. Symptoms like aphasia, disturb sleep, nightmare and hurting the self are the manifestation of the psychological trauma named hysteria which result from rape and violation. Freud claims that sexual molestation in childhood is the base of hysteria which appear later in the form of the aforementioned symptoms. This paper will shed light on Hysteria from Freudian perspective, in order to study its causes, symptoms, and how it influence females character and finally the action undertaken by these females to regain their subjectivity. This process of Abjection which take many steps, one of them explores Freudian talking therapy in which females retell their experiences and the suffering they endure throughout their life. The abandonment and the consequent psychological disturbances the characters were exposed to, as explained in this paper, forced Seneca and other characters to experience abjection which make them to construct their subjectivities.

\section{REFERENCES}

Breuer, J., and Freud, S. (1957). Studies on hysteria. New York: Basic Books.

Freud, S. (1975). Three Essays on the Theory of Sexuality. New York: Basic Books.

Freud, S. (1962). The aetiology of hysteria. Standard Edition of the Complete Psychological Works of Sigmund Freud, 3.

Freud, S. (1895). Studies on Hysteria.

Freud, S. (1900). The Interpretation of Dreams.

Heller, S. (2005). Freud A to Z. Hoboken.

Mijolla, A.D. (2005). International Dictionary of Psychoanalysis = Dictionaire international De La Psychoanalyse. Detroit: Mc Millon Reference USA, print

Showalter, E. (1985). The female malady: women, madness, and English culture, 1830-1980. New York: Pantheon Books.

Verhaeghe, P. (1999). Does the woman exist? From Freud's hysteric to Lacan's feminine. New York: Other Press.

Wald, C. (2007). Hysteria, trauma and melancholia: performative maladies in contemporary Anglophone drama. New York: Palgrave Macmillan. 